\title{
Residual Shear Strength of a Residual Soil of Granulite
}

\author{
M. Heidemann, L.A. Bressani, J.A. Flores
}

\begin{abstract}
This paper discusses the residual shear strength of a granulite residual soil that was involved in a large landslide in Brazil. The residual strength was investigated because of the great mobility achieved by the soil after failure. The experimental program comprised physical and mineralogical characterization and residual shear strength measurements. Direct shear tests show a progressive breakage of soil structure. In the tests the soil showed brittleness under the higher normal stresses. The residual friction angle measured in direct shear test is about $12.0^{\circ}$, remarkably smaller than $25.0^{\circ}$ measured in peak. For ring shear tests a linear failure envelope indicates a friction angle of $7.7^{\circ}$. The mobilization of the residual condition imposes a severe fall in shear strength and may explain the mobility presented by the soil during the reported landslide. Particle size analysis indicated that the material becomes finer after more energetic sample preparation, but the shearing did not cause significant particle disintegration. Most of the published correlations between the residual friction angle and clay fraction or plasticity index do not apply to this material.
\end{abstract}

Keywords: direct shear, residual strength, residual soil, ring shear, structured soil.

\section{Introduction}

Residual shear strength is important in understanding the stability of old landslides, in the assessment of the engineering properties of soil deposits which contain preexisting shear surfaces and for risk assessment of progressive failure in new and existing slopes (Lupini et al., 1981; Skempton \& Petley, 1967; Skempton, 1985). It is also important for the design of remedial measures (Stark \& Eid, 1994) and for the understanding the role of residual strength in first time failures (Mesri \& Shahien, 2003).

In problems associated with mobility of soil mass after instabilities due to liquefaction, some researchers use the term residual shear strength to describe the fully softened strength of soil (Norris et al., 1997; Wang et al., 2007; Dewoolkar et al., 2015). In such cases, the concept of residual shear strength is taken as the drop of shear strength by changes in porosity and excess of pore pressure in an undrained failure rather than by the processes described in the former papers (e.g.: Skempton \& Petley, 1967; Skempton, 1985).

In 2008, hundreds of landslides were reported in Southern Brazil after heavy rainfalls, many of them involving residual soils of granulite. In a specific case, the failure was triggered 14 days after the main rains ceased. The mobilized soil mass, detached from a $50 \mathrm{~m}$ high elevation, presented a high mobility and travelled about $500 \mathrm{~m}$ as a mudflow along a flat area until deposition.

One hypothesis is that after the landslide triggering the shear strength had dropped to residual values along the failure surface and inside the unstable soil mass, causing the acceleration and fluidization (with undrained condi- tions) of the soil. When the shear strains cause a decrease in the soil friction angle to values lower than the fully softened (critical value) and undrained conditions are created, the displacements necessary to reach equilibrium will be very large.

Considering this case, a study about residual shear strength of the soil involved in these landslides was conducted in order to investigate the validity of this hypothesis and to contribute to the understanding of the residual strength of tropical soils. This study was conducted in terms of drained residual shear strength and aimed to measure the shear strength parameters and assess the effects of the shearing process to the integrity of soil particles. Some observations concerning the influence of test type on the strength parameters measured, the form of sample preparation and the validity of correlations between residual friction angle and soil physical properties have been made. Drainage conditions during the movement of the unstable mass are not further discussed here.

Both direct shear device and ring shear device can be used to measure residual friction angle $\left(\phi^{\prime}{ }_{r}\right)$ as both allow unidirectional shearing of a soil specimen, but the second is considered the most reliable. But only the ring shear apparatus can apply large shear strains (or large displacements) without reversing the direction of the shearing process (Bishop et al., 1971; Bromhead, 1979; Tika, 1999; Suzuki et al., 2007; Skempton, 1985; Stark \& Eid, 1994; Watry \& Lade, 2000). Although ring shear apparatus are not commonly found, and many designers and researchers use direct shear tests results, Vithana et al. (2011) have shown that measurements of $\phi$, from direct shear are almost 2

Marcelo Heidemann, D.Sc., Associate Professor, Department of Mobility Engineering, Federal University of Santa Catarina, Joinville, SC, Brazil. e-mail: marcelo.heidemann@ufsc.br.

Luiz Antônio Bressani, Ph.D.,Full Professor, Department of Civil Engineering, Federal University of Rio Grande do Sul, Porto Alegre, RS, Brazil. e-mail: bressani@ ufrgs.br. Juan Altamirano Flores, D.Sc., Associate Professor, Department of Geology, Federal University of Santa Catarina, Florianópolis, SC, Brazil. e-mail: juan.flores@ ufsc.br. Submitted on September 5, 2018; Final Acceptance on February 14, 2020; Discussion open until August 31, 2020.

DOI: $10.28927 /$ SR. 431031 
times higher than those obtained from ring shear in tuffaceous clay and mudstone samples; circa of 1.02 to 1.3 in loess, siltstone and alluvial loess samples. Chen \& Liu (2013), on the other hand, measured similar values of $\phi$, using both techniques.

Most studies related to residual shear strength are focused on sedimentary and artificial soils (Skempton \& Petley, 1967; La Gatta, 1970; Bishop et al., 1971; Townsend \& Gilbert, 1973; Kenney, 1977; Lupini et al., 1981; Skempton, 1985; Skempton \& Vaughan; 1993; Stark \& Eid, 1994; Tiwari \& Marui, 2005; Wang et al., 2007; Toyota et al., 2009; Eid et al., 2016). There is much less residual shear strength data from residual soils formed through rock alteration under tropical and sub-tropical environments (Tanaka, 1976; Wesley, 1977; Boyce, 1985; Simões, 1991; Lacerda \& Silveira, 1992; Rigo et al., 2006).

Since mineralogy can control residual shear strength, as suggested by Hawkins \& Privett (1985), Skempton (1985), Stark \& Eid (1994), Chattopadhyay (1972), Vaughan et al. (1978), Meehan et al. (2010) and Collotta et al. (1989), much of the knowledge about residual shear strength of sedimentary and laboratory mixed soils does not necessarily apply to tropical residual soils (Boyce, 1985). In addition, Rigo et al. (2006) showed that measured values of $\phi$ ', in tropical soils from Southern Brazil are affected not only by soil mineralogy, effective normal stress and particle size distribution but also by particle weathering, parent rock and pedogenetic processes. That may be the reason why many authors have reported that largely used correlations between residual friction angle and simple physical indices, developed for sedimentary soils, do not apply to residual soils (Hayden et al., 2018; Stark \& Hussain, 2013; Wesley, 2003; Stark \& Eid, 1994; Boyce, 1985).

Since the works of Charles \& Soares (1984), Hawkins \& Privett (1985) and Skempton (1985), many other researchers have shown that the shear strength envelopes of clayey and plastic soils are nonlinear, especially at a low effective normal stress (Stark \& Hussain, 2013; Stark \& Eid, 1994; Mesri \& Shahien, 2003).

Particles of some residual soils can suffer disintegration by manipulation during the sample preparation or during the tests, as shown by Collins (1985), Silveira (1991) and Rigo (2005). Soils with partly altered minerals are prone to be crumbled. Thus, it is not simple to define precisely/definitely the amount of clayey or silty particles on these soils in order to predict the residual friction angle through a correlation and if the failure envelope will be linear or nonlinear.

Hoyos et al. (2014), Infante Sedano et al. (2007) and Merchán et al. (2011) showed the effects of suction on the residual strength of soils. Such results are important on soils that occur in unsaturated state and this condition is important in large areas of the world. For soils in tropical and humid areas and for failures preceded by rainy periods, the suction role does not seem significant considering that be- cause of the high saturation degree the suction level tends to be low (but should be evaluated in each case).

\section{Soil Description}

The soil studied occurs in Vale do Itajaí, Santa Catarina state, South Brazil. The coordinates of the studied area are UTM 696995E and 7024013S. The elevation is around $58 \mathrm{~m}$ above the sea level. The material was mobilized in a landslide that occurred in 2008, 14 days after a main event of heavy rainfalls (more than $700 \mathrm{~mm} / 4$ days). Such heavy rainfalls occurred after a period of more than 60 rainy days. The landslide scar and the deposited soil are shown in Fig. 1, as well as the $500 \mathrm{~m}$ path followed by the soil after the failure.

The soil is a residual soil from granulite that regionally occurs in soil profiles of thickness larger than $50 \mathrm{~m}$ without lateritic features even at small depth. A careful field inspection confirmed that relict structures were absent in the scar. Its main soil physical properties are presented in Table 1.
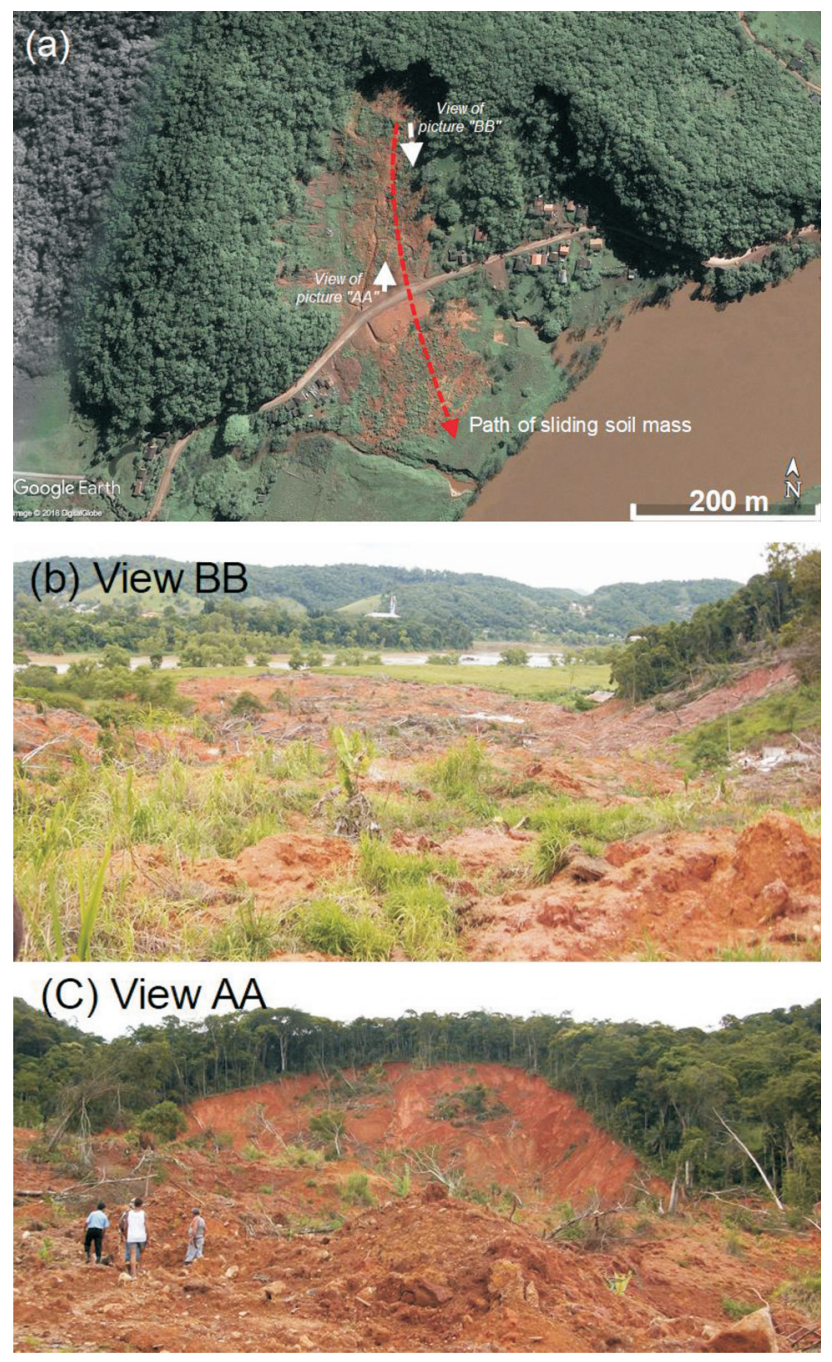

Figure 1 - Aerial view of studied area (a) and the mobilized soil after the landslide ( $b$ and $c$ ). 
Table 1 - Summary of physical properties.

\begin{tabular}{ll}
\hline$w_{L}^{(1)}$ & 47 \\
$w_{P}^{(1)}$ & 31 \\
$P_{I}^{(1)}$ & 16 \\
$G^{(2)}$ & 2.65 \\
$\gamma_{d}$ & $11.9 \mathrm{kN} / \mathrm{m}^{3}$ \\
$e$ & 1.21 \\
$w_{\text {nat }}{ }^{(3)}$ & $40.7 \%$ \\
$S_{r}^{(3)}$ & $87 \%$ \\
\hline
\end{tabular}

${ }^{(1)}$ According to D4318/2010 (ASTM); ${ }^{(2)}$ According to D854/2010 (ASTM); ${ }^{(3)}$ Measured 8 months after the event.

The soil water characteristic curve (SWCC), previously determined in accordance with the recommendations of D5298/2010 (ASTM), revealed that for the range of saturation degree in which this soil was sampled the suction levels were lower than $\sim 50 \mathrm{kPa}$. Considering the very wet period that preceded the landslide, the expected suction values should have been even lower. So, it is unlikely that suction had any significant role in the failure process and it was not taken into account.

In its natural state, the soil is composed mainly by silt as shown in the particle size curve (Fig. 2) obtained with the use of dispersive solution, according to procedures described in D422-63/2007 (ASTM). Before sieving, the crumbs of the soil were broken up using a mortar and rubber covered pestle. Care was taken to prevent disintegration or reduction of individual particles, using enough force as necessary to break up the aggregations without destroying the individual particles. The results revealed about $20 \%$ of clays and the soil is classified as a silt of low plasticity (ML) by the Unified Soil Classification System - USCS (ASTM D2487/2011). Tests without the dispersive solution were

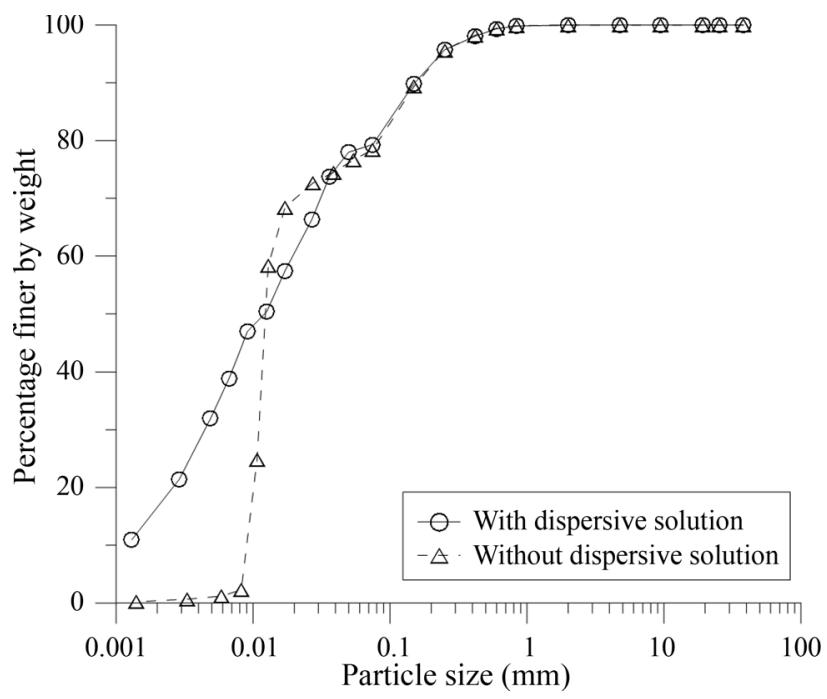

Figure 2 - Particle size curves of studied soil. also carried out and the difference between them is shown in Table 2 with the clay fraction being the most affected.

The differences observed in Fig. 2 may be in part explained through the analysis with Scanning Electron Microscope (SEM). The images reproduced in Fig. 3 were made from crumbles carefully extracted from the inner part of an undisturbed sample. The crumbles had about $5 \mathrm{~mm}$ diameter and before the analysis they were air dried for $96 \mathrm{~h}$ and then oven dried for $24 \mathrm{~h}$. Metallization of these samples was made by a first layer of carbon and a second layer of gold. SEM analysis was carried out in a SEM model JEOL JSM5800.

As shown in Fig. 3a some of the clay particles are grouped together forming clusters of silt and sand size. Other particles are adhered to larger particles (Fig. 3b). Feldspar crystals appear very altered and sometimes the cleavage planes are opened being susceptible to disintegration under mechanic actions (Fig. 3c).

In mineralogical terms, the soil is formed mainly by quartz, feldspars and kaolinite. Small amounts of illite and smectite were also found in X-ray diffractometry. These analyses were carried out in soil samples composed by particles smaller than $2 \mu \mathrm{m}$. With these fraction 4 pastilles were prepared: the first was analyzed in natural condition without orientation (powder), the second was analyzed in natural condition with orientation, the third was previously saturated with ethylene glycol (to find expansive minerals) and the last was previously heated at $550{ }^{\circ} \mathrm{C}$ for $2 \mathrm{~h}$ (for a better detection of kaolinite). The analyses were made using a diffractometer Siemens Bruker AXS, model D5000 with a goniometer $\theta-\theta$. The results were assessed with basis in the reference spectra of the JCPDS database.

\section{Experimental Program}

The soil was sampled in $15 \mathrm{~cm}$ edge blocks, in accordance with Brazilian Standard NBR 9604/1986 (ABNT). The blocks were extracted from the same location, in the middle of the landslide scar, which would represent around $6 \mathrm{~m}$ depth on the original profile. There was no visible heterogeneity in the exposed soil profile, except for the upper layer of organic topsoil.

Table 2 - Percentages of fractions obtained in the tests.

\begin{tabular}{lcc}
\hline Fraction $^{(1)}$ & $\begin{array}{c}\text { With dispersive } \\
\text { solution }\end{array}$ & $\begin{array}{c}\text { Without dispersive } \\
\text { solution }\end{array}$ \\
\hline Gravel & 0 & 0 \\
Coarse sand & 0 & 0 \\
Medium sand & 1.92 & 1.73 \\
Fine sand & 18.75 & 19.81 \\
Silt & 63.87 & 78.09 \\
Clay & 15.46 & 0.37 \\
\hline
\end{tabular}

${ }^{(1)}$ According to NBR 6502/1995 (ABNT). 

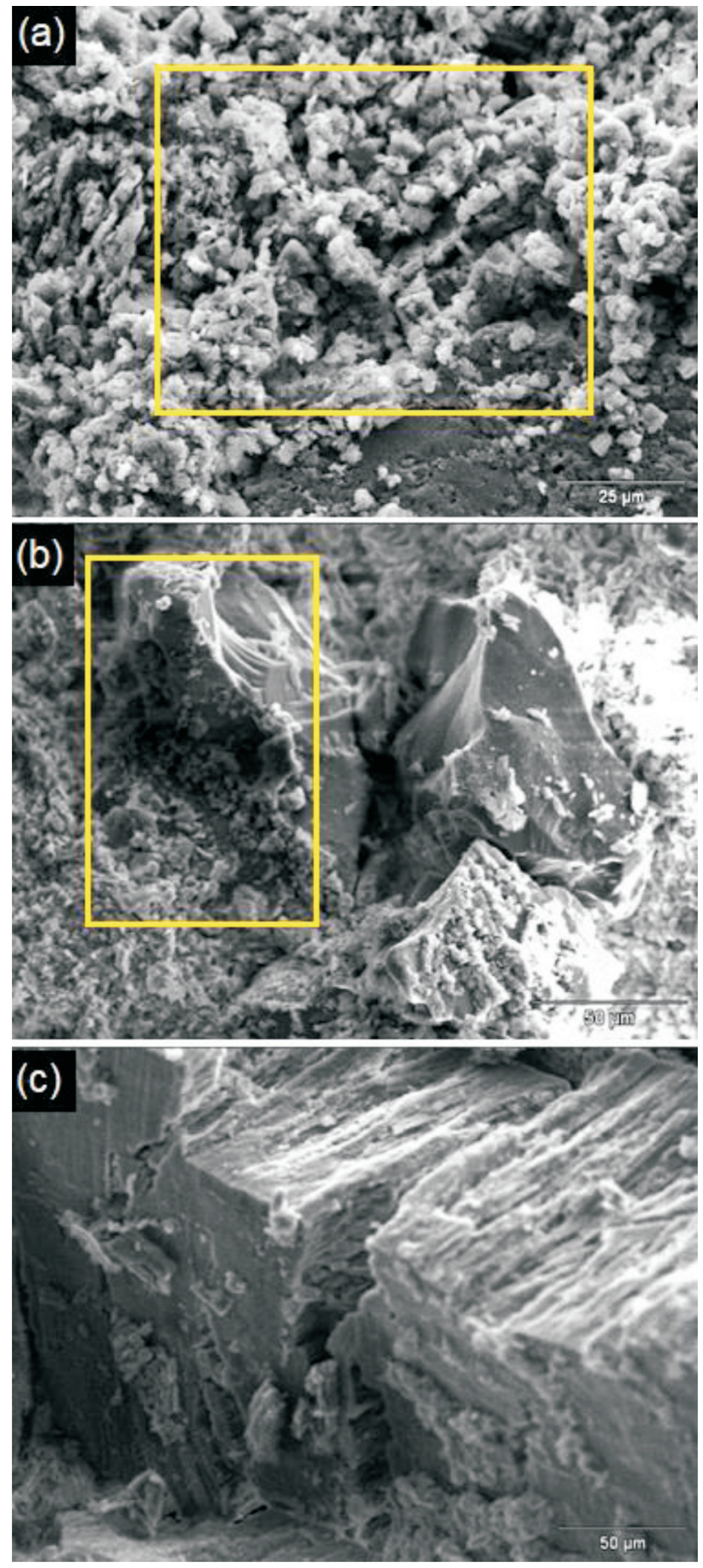

Figure 3 - Scanning electron microscopy images: (a) Detail in the box: silty size clusters formed by clays and fine silts; (b) Detail in the box: clays adhered to large quartz particle; (c) Cleavage of an altered feldspar crystal.

The position and orientation of the block samples were registered before moving them to the laboratory. Undisturbed specimens were trimmed from these blocks in order to guarantee that the shearing would occur in the same direction as the field failure. This was considered important as the original rock is metamorphic and the soil structure may preserve an anisotropic behavior. Direct shear tests have been carried on these undisturbed specimens according to general recommendations of D3080/2004 (ASTM).

The tests were carried out in saturated condition under effective normal stress of 50,100, 200 and $380 \mathrm{kPa}$. Drained tests were chosen as they seem to represent the soil condition up to the onset of larger mass displacements. After the landslide triggering, the shear conditions probably changed to undrained conditions due to the dramatic rate increase (there is no field monitoring to support this assumption).

Computation of the shear rate based on values of $t_{90}$ $\left(\mathrm{t}=\right.$ 11.6. $\left.\mathrm{t}_{90}\right)$ pointed out to a shear time of about $100 \mathrm{~min}$. Considering the soil classification (ML) the authors decided to use a value 2 times larger than the $200 \mathrm{~min}$ suggested by the D3080/2004 (ASTM) for this kind of soil. The shear rate chosen was $0.016 \mathrm{~mm} / \mathrm{min}$ that corresponds to $400 \mathrm{~min}$ for a displacement of $7.5 \mathrm{~mm}$. Each specimen was sheared 4 times: 3 reversal tests were carried out after the first one. To execute the reversals, normal stresses were reduced to $50 \mathrm{kPa}$ and, after repositioning the specimen in the starting point, the required normal stress was applied again, and the new shearing stage started.

Ring shear tests were carried out following the D6467/2006 (ASTM) instructions in an equipment originally described by Bromhead (1979). This apparatus requires remolded specimens, which were prepared with the soil fraction passing in the \#40 sieve. Before sieving, the crumbs of the soil were broken up using a mortar and rubber covered pestle. Care was taken to avoid disintegration or reduction of individual particles, using enough force as necessary to break up the aggregations without destroying the individual particles (as recommended in D6913/2009 (ASTM)). This procedure aimed to keep the microstructural features of the soil. Moisture content was corrected in order to reach the plastic limit ( $w_{P}=31 \%$ ) as suggested by Stark \& Vettel (1992) and Bromhead (1986). Distilled water was added to a soil sample of known dry mass and manually mixed and homogenized. The sample was kept hermetically closed in a bag for $48 \mathrm{~h}$ in order to obtain homogenization. The ring shear cell was filled manually, pressing the soil with a spatula until filling up the shear cell. The tests were performed with effective normal stress ranging from 25 to $600 \mathrm{kPa}$ adopting a single stage technique (i.e. for each stress level one specimen was tested). Prior to the measuring test, a pre-shearing step was carried out to rapidly reach the residual strength condition (Anayi et al., 1988; Stark \& Vettel, 1992). The rate used during the tests was $0.12 \% \mathrm{~min}(0.089 \mathrm{~mm} / \mathrm{min})$, which is considered slow enough to prevent the occurrence of excesses of pore pressure. The drainage occurs through the top and the bottom of the specimen where there are porous rings.

The granulometry of the soil used in one ring shear test $\left(\sigma^{\prime}=200 \mathrm{kPa}\right)$ was determined before the test after specimen assembling and after the test with the soil sample 
being taken from the region along the shear surface. As the amount of soil available was small, sieving and sedimentation procedures could not be used. Laser scanning was employed instead, using a CILAS 1180 apparatus without the use of dispersive agents. The analyses were made in a powder sample through the consideration of their light-scattering properties based on ISO 13320-1/2009 recommendations.

\section{Results and Discussions}

The initial physical characteristics of soil specimens used in direct shear tests are shown in Table 3. All the specimens presented almost the same unit weight, porosity and saturation degree with the exception of the specimen used in the test under effective normal stress of $380 \mathrm{kPa}$, which had lower void ratio and higher dry unit weight.

Figure 4 shows the direct shear results (stress-displacement curves) including the magnitude of shear strength parameters in (a) peak, (b) after the first shearing

Table 3 - Physical properties of specimens used in direct shear tests.

\begin{tabular}{lcccc}
\hline & $50 \mathrm{kPa}$ & $100 \mathrm{kPa}$ & $200 \mathrm{kPa}$ & $380 \mathrm{kPa}$ \\
\hline$w(\%)$ & 40.3 & 40.0 & 42.0 & 39.0 \\
$\gamma\left(\mathrm{kN} / \mathrm{m}^{3}\right)$ & 16.3 & 16.2 & 16.4 & 16.6 \\
$\gamma_{d}\left(\mathrm{kN} / \mathrm{m}^{3}\right)$ & 11.6 & 11.5 & 11.5 & 11.9 \\
$e$ & 1.24 & 1.25 & 1.25 & 1.18 \\
$S_{r}(\%)$ & 86.3 & 84.7 & 89.7 & 87.6 \\
\hline
\end{tabular}

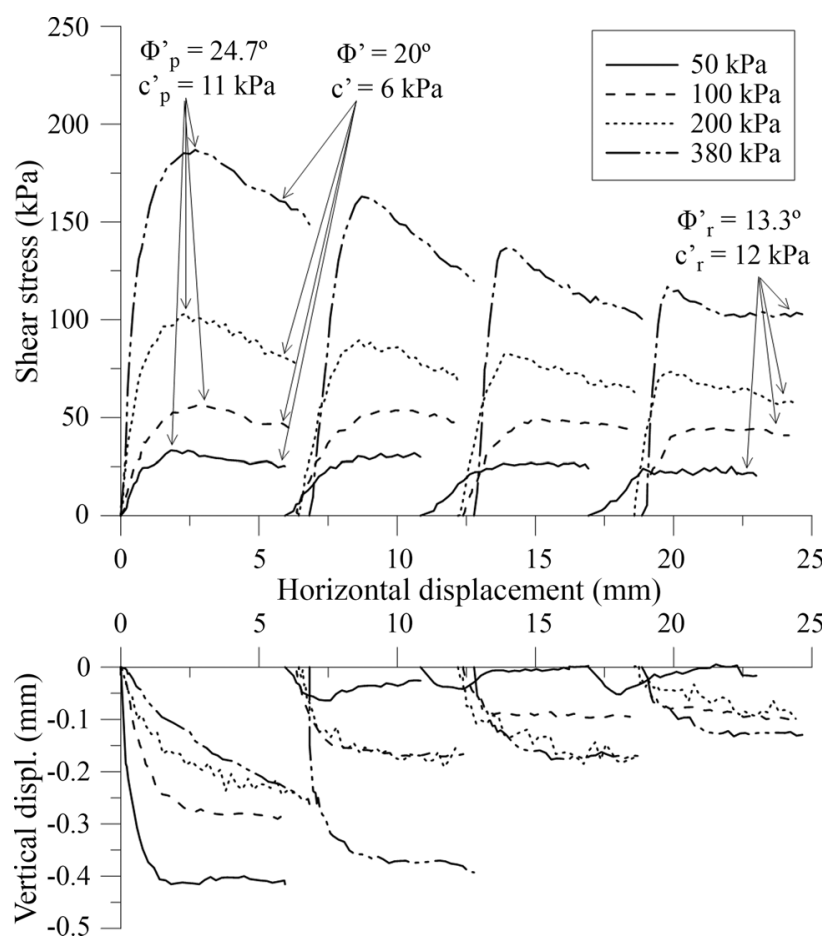

Figure 4 - Results of direct shear tests. stage and (c) at large strain condition (end of test). Although a reduction of mobilized shear stress can be observed under all the normal stresses tested, this reduction is much clearer under $200 \mathrm{kPa}$ and $380 \mathrm{kPa}$ as a more brittle behavior can be observed. So, besides the shear displacement, the importance of higher normal stress is quite remarkable in the mobilization of residual strength.

At the beginning of each shear reversal stage, the mobilized shear stress is higher than measured at the end of the previous stage. This is probably due to the partial disarrangement of the particle alignment caused by the reversal process itself, a common criticism of this technique (see Stark \& Eid, 1994; Skempton \& Petley, 1967; Skempton, 1985; Stark \& Vettel, 1992; Hawkins \& Privett, 1985), but the shearing stress dropped very quickly with the straining.

Except for the tests under $\sigma^{\prime}=50 \mathrm{kPa}$, the behavior is typically contractive in all tests. The contraction in the first shear stage of the test under $\sigma^{\prime}=50 \mathrm{kPa}$ is probably due to voids reduction, which does not occur during consolidation with higher normal stresses. Unfortunately, due to limitations of the direct shear apparatus, such data cannot be examined quantitatively.

The peak shear strength parameters were derived from the highest shear stress measured in each test. The failure envelope for post peak shear strength was defined from a stable value of shear stress or from that for a displacement of $10 \%$. The failure criterion for residual conditions was defined from the final stable value of shear stress at the $4^{\text {th }}$ stage.

Although large displacements are required for the mobilization of the (minimum) residual shear strength, considering the final mobilized shear stress of the 4th stages (4 tests), a linear failure envelope was obtained resulting in a residual friction angle $\left(\phi^{\prime}{ }_{r}=13^{\circ}\right)$ and cohesive intercept $\left(c^{\prime}{ }_{r} \sim 12 \mathrm{kPa}\right)$, which represent a remarkable drop from the peak strength.

The initial physical properties of the remolded specimens used on ring shear tests are presented in Table 4. These specimens were molded with higher density than undisturbed specimens to prevent that after the consolidation step the specimens become too thin.

The stress-displacement curves obtained from ring shear tests on remolded samples are shown in Fig. 5. The mobilized shear stress becomes stable when displacements exceeded about 20-30 mm. The tests with normal stresses

Table 4 - Physical properties of specimens used on ring shear tests.

\begin{tabular}{ll}
\hline$w(\%)$ & 31.0 \\
$\gamma\left(\mathrm{kN} / \mathrm{m}^{3}\right)$ & 16.7 \\
$\gamma_{d}\left(\mathrm{kN} / \mathrm{m}^{3}\right)$ & 12.8 \\
$e$ & 1.03 \\
$S_{r}(\%)$ & 79.4 \\
\hline
\end{tabular}


of 400 and $600 \mathrm{kPa}$ showed small shear strength peaks even after the pre-shear procedure (as reported by Lupini et al., 1981).

Figure 6 shows the effective normal stress plotted against stress ratio $\left(\tau / \sigma^{\prime}\right)$ and friction angle derived for the end of the tests. The data indicate that the residual friction angle is affected by effective normal stress and the failure envelope is not linear. This is typical of soils in which sliding is the mechanism that controls the mobilization of residual strength, as high stress and/or displacement converts edge-to-face to face-to-face particle interactions, according to Stark \& Eid (1994). In this soil, this is probably due to the high proportion of flatty particles, including some silts (as suggested by Anderson \& Hammoud, 1988; Hawkins \& Privett, 1985). Other authors such as Stark \& Eid (1994) and Skempton (1985) report such non-normalization as caused by large amount of clay particles, which is not the case in this soil. The non-linearity of the failure envelope becomes clearer for effective normal stresses higher than $400 \mathrm{kPa}$ (Fig. 7).

Shear strength parameters derived from these ring shear and direct shear tests are summarized in Table 5. The failure criterion adopted was the stabilization of mobilized shear stress at the test end.

The value of the residual friction angle $\left(\phi{ }_{r} \sim 7.7^{\circ}\right)$ also indicates the occurrence of a sliding failure (Lupini et

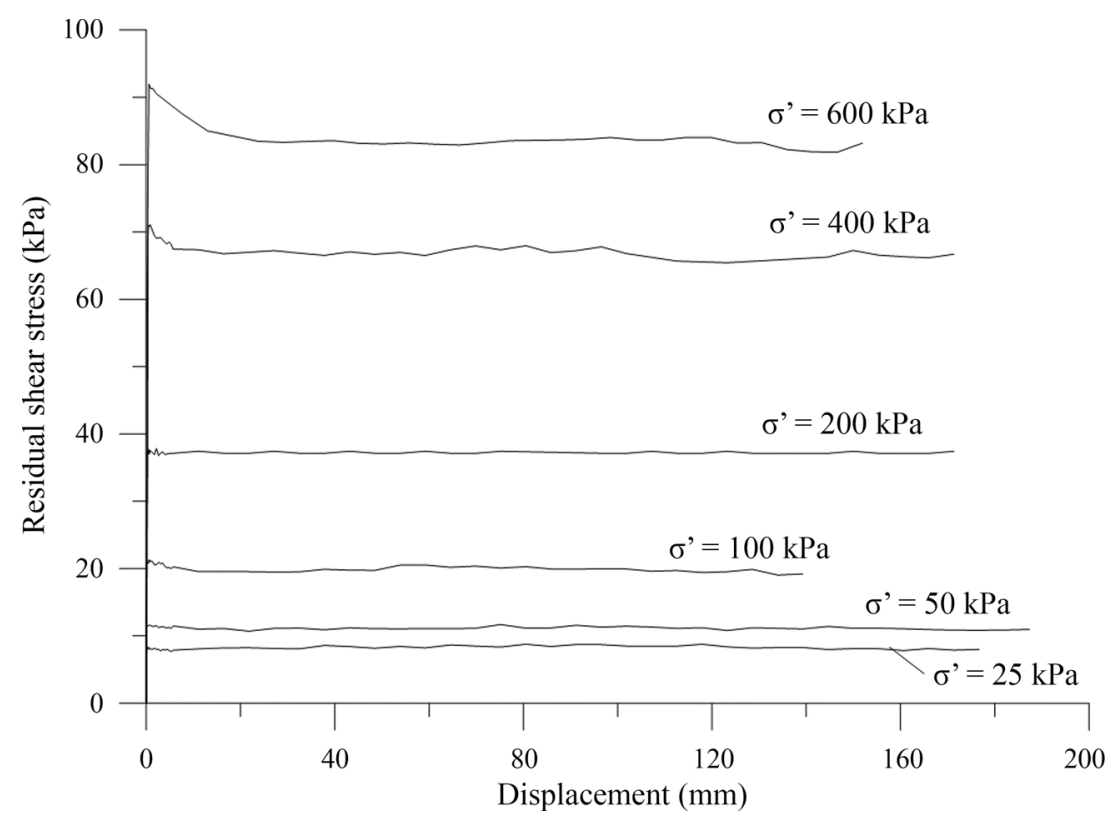

Figure 5 - Shear stress-displacement curves from ring shear tests.

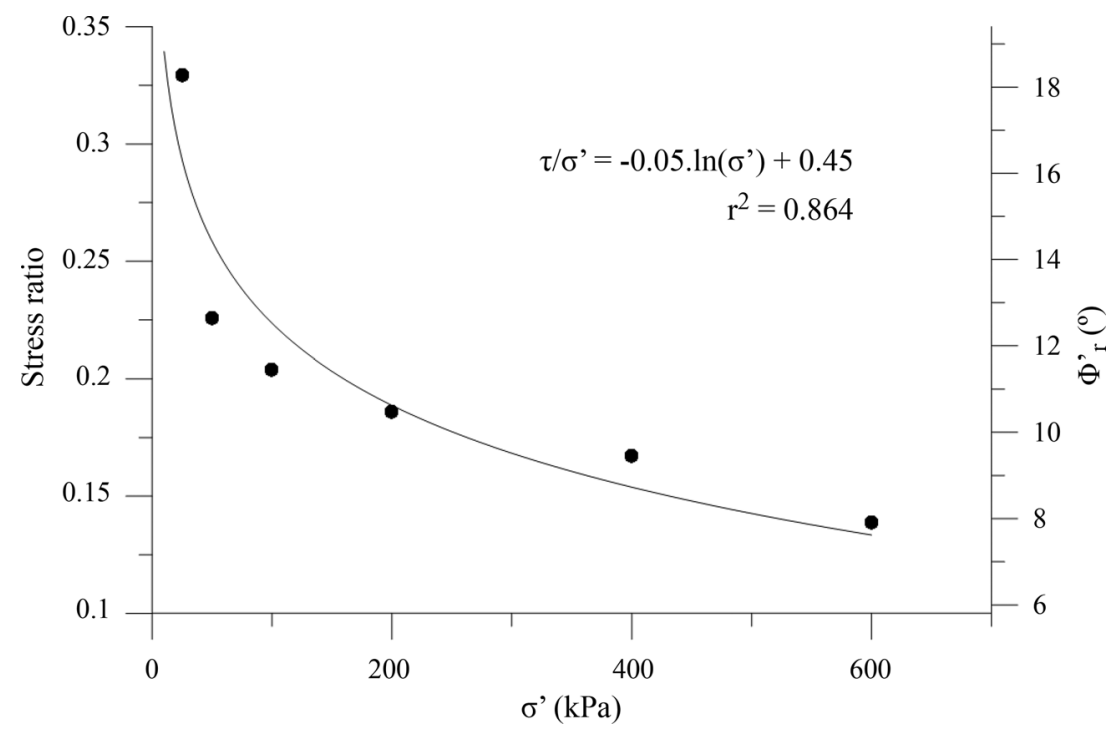

Figure 6 - Stress ratio and friction angle $v s$. effective normal stress. 


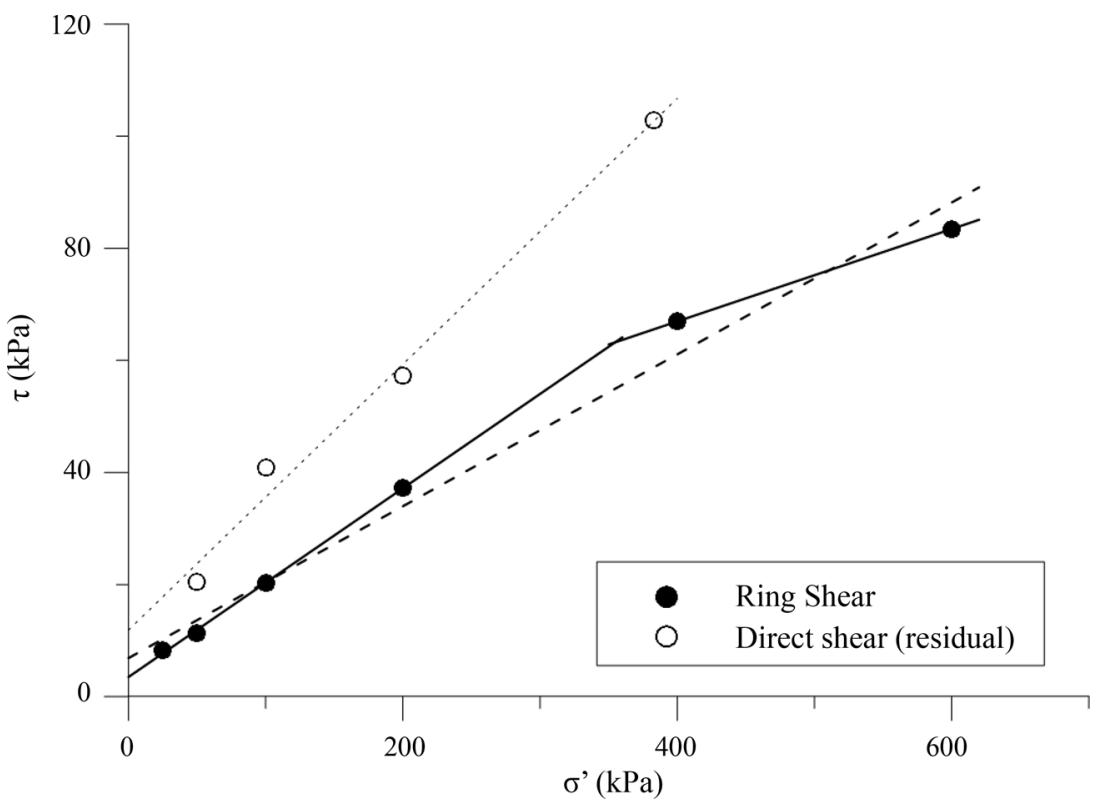

Figure 7 - Shear strength envelopes.

Table 5 - Summary of measured residual shear strength parameters.

\begin{tabular}{lccc}
\hline Condition & $\phi^{\prime}{ }_{r}\left({ }^{\circ}\right)$ & $c^{\prime}{ }_{r}(\mathrm{kPa})$ & $r^{2}$ \\
\hline Ring shear $\left(\sigma^{\prime}{ }_{n}=25-600 \mathrm{kPa}\right)$ & 7.7 & 6.9 & 0.984 \\
Ring shear $\left(\sigma^{\prime}=25-600 \mathrm{kPa}\right), c^{\prime}=0$ & 8.6 & 0 & 0.957 \\
Ring shear $\left(\sigma^{\prime}=25-400 \mathrm{kPa}\right)$, bilinear & 9.0 & 4.3 & 0.999 \\
Ring shear $\left(\sigma^{\prime}=400-600 \mathrm{kPa}\right)$, bilinear & 4.7 & 34.0 & 1.000 \\
Direct shear with reversals & 13.3 & 12.0 & 0.988 \\
Direct shear with reversals, $c^{\prime}=0$ & 15.7 & 0 & 0.939 \\
\hline
\end{tabular}

al., 1981). On the other hand, according to the correlation developed by Mitchell (1993), the purely clayey fraction of this soil (computed from the test with dispersive solution) would lead to a turbulent shearing, without a smooth and well-defined shearing surface.

According to Kenney (1977), the sliding-like residual strength is strongly linked to the lamellar particle mineralogy. Lupini et al. (1981) associate low residual friction angles with the domain of montmorillonite clay minerals, while high residual friction angles would be linked to the presence of kaolinites and illites. And, although X-ray diffraction analyses indicate the predominance of kaolinite in the soil, it presented a low residual friction angle, contrary to the tendency presented by pure kaolinites studied by Tiwari \& Marui (2005) and Lupini et al. (1981).

Adjusting linear envelopes to direct shear experimental data gives a $\phi^{\prime}$, that is 1.7 times higher than that obtained from ring shear tests considering $c^{\prime}{ }_{r}>0$ and 1.8 times if $c^{\prime}=0$. As residual friction angles are typically low, even small differences generate large percentage differences that reflects on the calculated stability safety factors.
Skempton (1985), Stark \& Eid (1994) and Watry \& Lade (2000) had already reported differences in this sense. Considering the more recent results presented by Vithana $e t$ al. (2011), the values measured in this work are consistent and fall between the observed by those authors in sedimentary clayey and sandy soils.

The process of sample preparation for ring shear test seems to cause some soil disaggregation, albeit small. Figure 8 shows particle size distribution curves of natural soil and of soil subjected to ring shear tests, obtained following D422-63/2007 (ASTM) recommendations. It is important to remember that particles larger than $0.42 \mathrm{~mm}$ had been removed from the specimens for the ring shear testing $(<2 \%)$.

The soil manipulation during preparation of ring shear test specimens caused some soil aggregate disintegration mainly in the range between 0.04 and $0.3 \mathrm{~mm}$. Probably such disintegration reaches sandy and silty clusters and partially altered feldspars. But the grading did not change significantly due to the shearing itself (see soil curves before and after testing - Figure 8). The testing did increase 


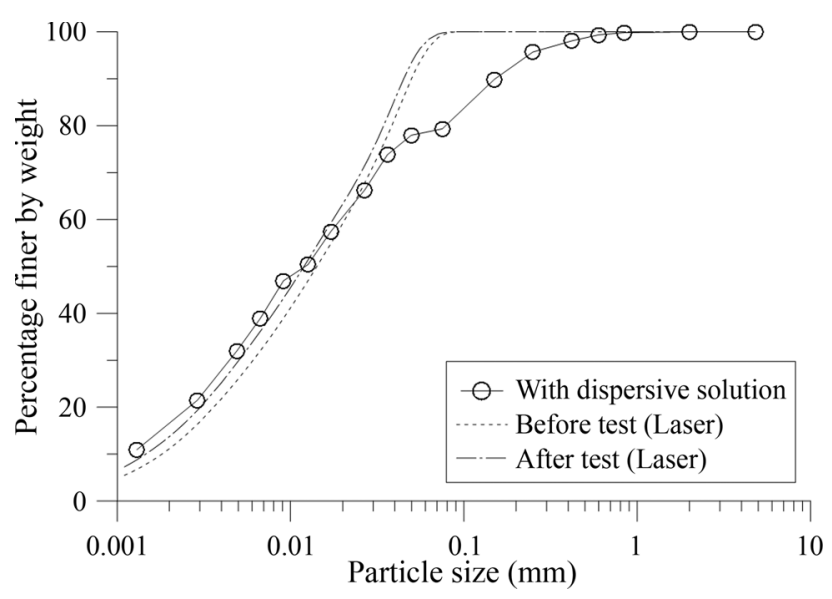

Figure 8 - Curves for the soils used in ring shear tests and reference grading curve.

the clay content (particles $<0.002 \mathrm{~mm}$ ) by about $2.5 \%$. Consequently, the low residual shear strength of this soil seems to be associated to alignment of the particles parallel to the shear surface and some disintegration of soil clusters rather than individual soil particles breakage. On the other hand, the soil clustering may explain the large difference between peak and residual friction angle in direct shear tests.

None of the correlations between $\phi^{\prime}$, (ring shear linear envelope with $c^{\prime}>0$ or $c^{\prime}=0$ ) and clay fraction or plasticity index, as proposed by Lupini et al. (1981), were able to successfully predict the behavior of this soil as shown in Fig. 9.

In contrast, the chart presented by Rigo et al. (2006), which shows the relationship between $\phi_{r}{ }_{r}$ and $P_{I}$ found for quite a number of different soils, including various tropical soils, seems consistent with the results obtained here (Fig. 10). The soil studied here presents a similar behavior to soils tested by Rigo et al. (2006) with partially weathered minerals, also having a low friction angle and low $P_{I}$. According to those authors, such behavior is due to the disintegration of some minerals promoted by large displacements and subsequent particle reorientation. The same explanation appears to apply to the studied soil.

It is important to emphasize that this chart was not proposed by those authors to correlate the residual friction angle to $P_{l}$, but rather to state that, in some soils that are not sedimentary, this property can have a large variation compared to the observed results described by the classical work of Skempton and co-authors. Although volcanic ash soils have a large $P_{I}$ and a much higher than expected value of $\phi^{\prime}$, the tropical soils with partly weathered minerals (most with clay particles inside them) have a low $P_{I}$ and a very low value of $\phi^{\prime}{ }_{r}$. So, Fig. 10 shows the importance of understanding that the expected behavior of soils is largely dependent on which group the soil belongs to (sedimentary clays and sands, lateritic soils, volcanic ash, residual soils with degradable minerals or micaceous).
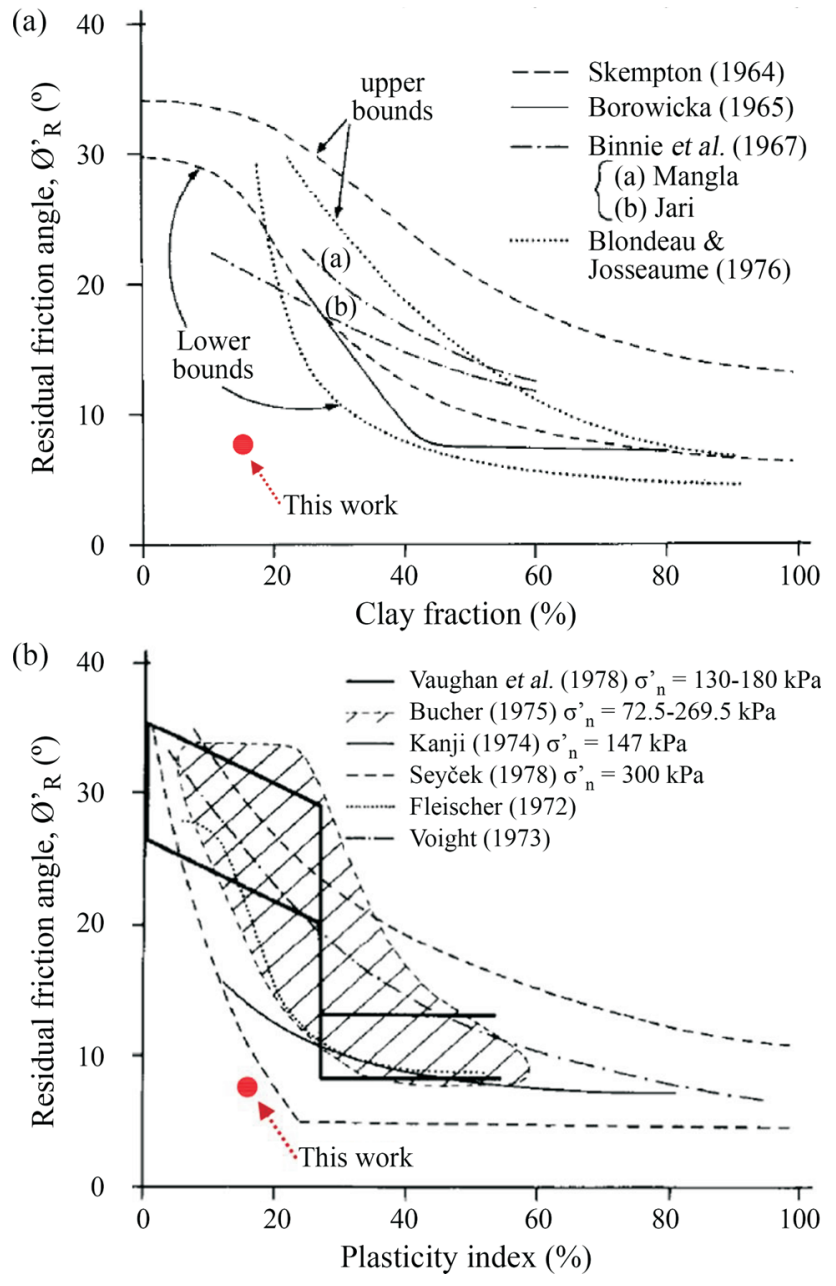

Figure 9 - Residual strength correlations with clay fraction (a) and plasticity index (b) (modified from Lupini et al., 1981).

\section{Conclusions}

Ring shear tests on specimens of granulite residual soil resulted in an average residual friction angle of $7.7^{\circ}$ associated to a sliding mode of failure, despite the small amount of clay minerals in its composition. Compared to data of sedimentary soils this value is quite low considering the small clay fraction in its composition. Reversal direct shear test results gave a higher 'residual' friction angle $\left(12^{\circ}\right)$ as the reversals cause particle misalignment. The obtained failure envelope was linear.

Specimen preparation for ring shear tests caused some disintegration of clusters of silt and fine sand size and increased the amount of free fine particles. In the laboratory tests, the shearing process does not seem to cause further disintegration as there are small differences between the pre and post-test particle size distribution curves (the clay fraction increased by $2.5 \%$ ).

The chart presented by Rigo et al. (2006) showed that the correlation between $\phi^{\prime}{ }_{r}$ and $P_{l}$ is dependent on soil origin and composition. The soil tested presented a relation- 


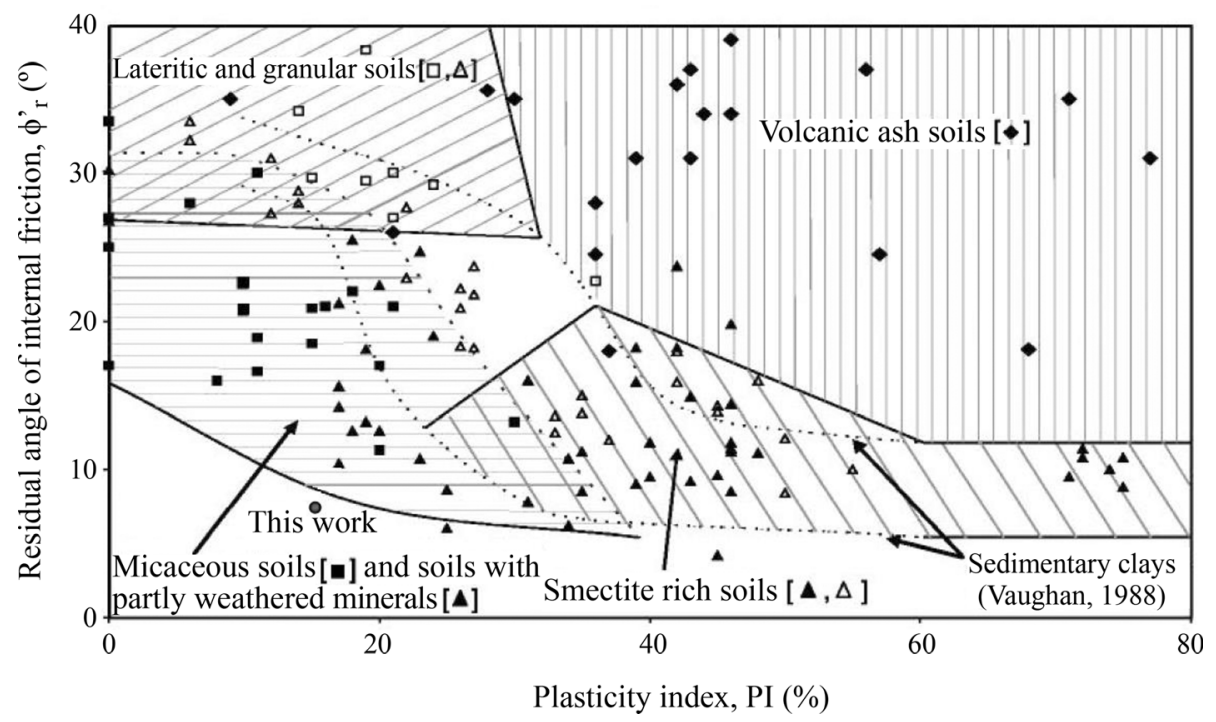

Figure 10 - Tropical soils grouped according to observed residual shear strength and $P_{I}$ (modified from Rigo et al., 2006).

ship between $\phi^{\prime}{ }_{r}$ and $P_{I}$ that is in accordance with that found by those authors for soils with partly weathered minerals, and which has a very different behavior with $P_{I}$ than that found previously by Skempton and co-workers.

This much lower than expected $\phi{ }_{r}$, found here seems to be associated with particle disintegration and its subsequent orientation by shearing. This disaggregation can be observed in the laboratory during manual specimen preparation. But the particle size distribution curves obtained before and after the shearing tests are very similar, thus implying that most of the soil clusters have been degraded during the test sample preparation. Ring shear tests have shown that effective normal stresses have some importance in the particle alignment mechanism: the residual friction angle reduces at larger normal effective stresses.

This data suggests that, as shearing displacements approach failure in the field, there will be soil aggregate disintegration and reduction of internal friction angle, as observed in reversal direct shear tests. There will be a strength reduction from peak to the fully mobilized residual shear strength (to values similar to ring shear test results). Accordingly, such behavior can explain the very fast landslide failure, as described by eyewitnesses, associated to a remarkably quick shear strength reduction from peak to fully mobilized residual strength (associated to cluster destruction and particle alignment).

\section{References}

ASTM (2003). Standard Test Method for Particle Size Analysis of Soils - D 422-63. ASTM International, West Conshohocken, Pennsylvania, USA, 8 p.

ABNT (1995). Rochas e Solos - NBR 6502. Associação Brasileira de Normas Técnicas. Rio de Janeiro, Brasil, $18 \mathrm{p}$.
ABNT (1986). Abertura de Poço e Trincheira de Inspeção em Solo, com Retirada de Amostras Deformadas e Indeformadas - Procedimento - NBR 9604. Associação Brasileira de Normas Técnicas, Rio de Janeiro, Brasil, $9 \mathrm{p}$.

Anayi, J.T.; Boyce, J.R. \& Rodgers, C.D. (1988). Comparison of alternative methods of measuring the residual strength of a clay. Transportation Research Board (TRB), Washington, pp. 16-26.

Anderson, W.F. \& Hammoud, F. (1988). Effect of testing procedure in ring shear tests. Geotechnical Testing Journal, 40(3):204-207.

ASTM (2011). Standard Practice for Classification of Soils for Engineering Purposes (Unified Soil Classification System) - D 2487-11. ASTM International, West Conshohocken, PA, USA, $12 \mathrm{p}$.

ASTM (2004). Standard Test Method for Direct Shear Test of Soils Under Consolidated Drained Conditions - D 3080-04. ASTM International, West Conshohocken, PA, USA, $7 \mathrm{p}$.

ASTM (2007). Standard Test Method for Particle-Size Analysis of Soils - D 422-63. ASTM International, West Conshohocken, PA, USA 8 p.

ASTM (2010). Standard Test Methods for Liquid Limit, Plastic Limit, and Plasticity Index of Soils - D 4318-10. ASTM International, West Conshohocken, PA, USA, $16 \mathrm{p}$.

ASTM (2010). Standard Test Method for Measurement of Soil Potential (Suction) Using Filter Paper - D 5298-10. ASTM International, West Conshohocken, PA, USA, $6 \mathrm{p}$.

ASTM (2006). Torsional ring shear test to determine drained residual shear strength of cohesive soils - D 646706. ASTM International, West Conshohocken, PA, USA, $6 \mathrm{p}$. 
ASTM (2009). Standard Test Methods for Particle-Size Distribution (Gradation) of Soils Using Sieve Analysis - D 6913-04. ASTM International, West Conshohocken, PA, USA, 33 p.

ASTM (2010). Standard Test Methods for Specific Gravity of Soil Solids by Water Pycnometer - D 854-10. ASTM International, West Conshohocken, PA, USA, 7 p.

Bishop, A.W.; Green, G.E.; Garga, V.K.; Andresen, A. \& Brown, J.D. (1971). A new ring shear apparatus and its application to the measurement of residual strength. Géotechnique, 21(4):273-328.

Boyce, J.R. (1985). Some observations on the residual strength of tropical soils. Proc. Int. Conf. Geomechanics in Tropical Lateritic and Saprolitic Soils, ABMS, São Paulo, pp. 229-237.

Bromhead, E.N. (1979). A simple ring shear apparatus. Ground Engineering, 12(5):40-44.

Bromhead, E.N. (1986). The Stability of Slopes. Chapman and Hall, London.

Charles, J.A. \& Soares, M.M. (1984). The stability of slopes in soils with nonlinear failure envelopes. Can. Geotech. J., 21(3):397-406.

Chattopadhyay, P.K. (1972). Residual Shear Strength of Some Pure Clay Mineral. Ph.D. Thesis, University of Alberta, Edmonton, 340 p.

Chen, X.P. \& Liu, D. (2013) Residual strength of slip zone soils. Landslides, 11(2):305-314.

Collins, K. (1985). Towards characterization of tropical soil microstructure. Int. Conf. Geomechanics in Tropical Lateritic and Saprolitic Soils, v. 1. ABMS, São Paulo, pp. 85-96.

Collotta, T.; Cantoni, R.; Pavesi, U.; Ruberl, E. \& Moretti, P.C. (1989). A correlation between residual friction angle, gradation and the index properties of cohesive soils. Géotechnique, 39(2):343-346.

Dewoolkar, M.P.E.; Hargy, J.; Anderson, I.; Alba, P. \& Olson, S.M. (2015) Residual and postliquefaction strength of a liquefiable sand. J. Geotech. Geoenviron. Eng., 142(2):04015068-1-04015068-11.

Eid, H.T.; Rabie, K.H. \& Wijewickreme, D. (2016). Drained residual shear strength at effective normal stresses relevant to soil slope stability analyses. Engineering Geology, 204:94-107.

Hawkins, A.B. \& Privett, K.D. (1985). Measurement and use of residual shear strength of cohesive soils. Ground Engineering, 18(8):22-29.

Hayden, C.P.; Purchase-Sanborn, K. \& Dewoolkar, M. (2018). Comparison of site-specific and empirical correlations for drained residual shear strength. Géotechnique, 68(12):1099-1108.

Hoyos, L.R.; Velosa, C.L. \& Puppala, A.J. (2014). Residual shear strength of unsaturated soils via suction-controlled ring shear testing. Engineering Geology, 172:1-11.
Infante Sedano, J.A.; Vanapalli, S.K. \& Garga, V.K. (2007). Modified ring shear apparatus for unsaturated soils testing. Geotech. Test. J., 30(1):1-9.

ISO (2009). Particle Size Analysis - Laser Diffraction Methods - 13320. International Organization for Standardization, Geneva, Switzerland, 51 p.

Kenney, T.C. (1977). Residual strength of mineral mixtures. Proc. $9^{\text {th }}$ International Conference in Soil Mechanics, Tokyo, pp. 155-160.

La Gatta, D.P. (1970). Residual Strength of Clays and Clay-Shales by Rotation Shear Tests. Harvard University, Cambridge, 220 p.

Lacerda, W.A. \& Silveira, G.C. (1992). Características de resistência ao cisalhamento e de compressibilidade dos solos residuais e coluvionares da encosta do Soberbo, RJ. Proc. $1^{\text {st }}$ Brazilian Symposium on Landslides, ABMS, Rio de Janeiro, pp. 445-461.

Lupini, J.F.; Skinner, A.E. \& Vaughan, P.R. (1981). The drained residual strength of cohesive soils. Géotechnique, 31(2):181-213.

Meehan, C.L.; Brandon, T.L.; Duncan, J.M. \& Tiwari, B. (2010). Direct shear testing of polished slickensided surfaces. Landslides, 7(2):157-167.

Merchán, V.; Romero, E. \& Vaunat, J. (2011). An adapted ring shear apparatus for testing partly saturated soils in the high suction range. Geotech. Test. J., 34(5):433444.

Mesri, G. \& Shahien, M. (2003). Residual shear strength mobilized in first-time slope failures. J. Geotech. Geoenv. Eng., 129(1):12-31.

Mitchell, J.K. (1993). Fundamentals of Soil Behavior. 2nd ed. John Wiley and Sons, New York, 437 p.

Norris, G.; Siddharthan, R.; Zafir, Z. \& Madhu, R. (1997). Liquefaction and residual strength of sands from drained triaxial tests. J. Geotech. Geoenviron. Eng., 123(3):220-228.

Rigo, M.L. (2005) Mineralogia, Intemperismo e Comportamento Geotécnico de Solos Saprolíticos de Rochas Vulcânicas da Formação Serra Geral. Tese de Doutorado, Universidade Federal do Rio Grande do Sul, Porto Alegre, 347 p.

Rigo, M.L.; Pinheiro, R.J.B.; Bressani, L.A.; Bica, A.V.D. \& Silveira, R.M. (2006). The residual shear strength of tropical soils. Canadian Geotech. J., 43(4):431-447.

Silveira, G.C. (1991). Considerações sobre a granulometria dos solos residuais e coluvionares do escorregamento na estrada do soberbo - RJ. Solos e Rochas, 14(1):5962.

Simões, P.R.M. (1991). Mecanismos de Instabilização em Taludes Naturais em Formações Expansivas da Bacia Sedimentar do Recôncavo Baiano. Tese de Doutorado, Universidade Federal do Rio de Janeiro, Rio de Janeiro, 277 p.

Skempton, A.W. \& Petley, D.J. (1967). The strength along structural discontinuities in stiff clays. Proc. Geotech- 
nical Conference on Shear Strength Properties of Natural Soils and Rock, NGI, Oslo, pp. 29-46.

Skempton, A.W. \& Vaughan, P.R. (1993). The failure of Carsington dam. Géotechnique, 43(1):151-153.

Skempton, A.W. (1985). Residual strength of clays in landslides, folded strata and the laboratory. Géotechnique, 35(1):3-18.

Stark, T.D. \& Eid, H.T. (1994). Drained residual strength of cohesive soils. J. Geotech. Eng., 120(5):856-871.

Stark, T.D. \& Hussain, M. (2013). Empirical correlations: drained shear strength for slope stability analyses. J. Geotech. Geoenviron. Engineering, 139(6):853-862.

Stark, T.D. \& Vettel, J.J. (1992). Bromhead ring shear test procedure. Geotechnical Testing Journal, 15(1):24-32.

Suzuki, M.; Tsuzuki, S. \& Yamamoto, T. (2007) Residual strength characteristics of naturally and artificially cemented clays in reversal direct box shear test. Soils and Foundations, 47(6):1029-1044.

Tanaka, A. (1976) Algumas Considerações sobre a Resistência ao Cisalhamento do Solo Residual de Basalto de São Simão. Dissertação de Mestrado PUC-Rio, Rio de Janeiro, $145 \mathrm{p}$.

Tika, T.E. (1999) Ring shear tests on a carbonate sandy soil. Geotech Test Journal, 22(4):342-355.

Tiwari, B. \& Marui, H. (2005). A new method for the correlation of residual shear strength of the soil with mineralogical composition. J. Geotech. Geoenviron. Engineering., 131(9):1139-1150.

Townsend, F.C. \& Gilbert, P.A. (1973). Tests to measure residual strengths of some clay shales. Géotechnique, 23(2):267-271

Toyota, H.; Nakamura, K.; Sugimoto, M. \& Sakai, N. (2009). Ring shear tests to evaluate strength parameters in various remoulded soils. Géotechnique, 59(8):649659.

Vaughan, P.R.; Hight, D.W.; Sodha, V.G. \& Walbancke, H.J. (1978). Factors controlling the stability of clay fills in Britain. Proc. ICE Conf. on Clay Fills, Thomas Telford, London, pp. 205-217.

Vithana, S.B.; Nakamura, S.; Gibo, S.; Yoshinaga, A. \& Kimura, S. (2011). Correlation of large displacement drained shear strength of landslide soils measured by di- rect shear and ring shear devices. Landslides, 9(3):305314.

Voight, B. (1973). Correlation between Atterberg plasticity limits and residual shear strength of natural soils. Géotechnique, 23(2):265-267.

Wang, G.; Sassa, K.; Fukuoka, H. \& Tada, T. (2007). Experimental study on the shearing behavior of saturated silty soils based on ring-shear tests. J. Geotech. Geoenv. Eng., 133(3):319-333.

Watry, S.M. \& Lade, P.V. (2000). Residual shear strength of bentonites on Palos Verdes Peninsula, California. Proc. Slope Stability 2000, Geotechnical Special Publication n. 101, ASCE, Reston, pp. 323-342.

Wesley, L.D. (1977). Shear strength properties of halloysite and allophane clays in Java, Indonesia. Géotechnique, 27(2):125-136.

Wesley, L.D. (2003). Residual strength of clays and correlations using Atterberg limits. Géotechnique, 53(7):669-672.

\section{List of Symbols and Acronyms}

$\sigma$ ': effective normal stress

$\tau$ : shear stress

c': cohesive intercept

$\mathrm{c}^{\prime}$ : residual cohesive intercept

$\mathrm{c}_{\mathrm{p}}$ : peak cohesive intercept

$\phi '$ : friction angle

$\phi_{\mathrm{r}}$ : residual friction angle

$\phi_{\mathrm{p}}^{\prime}$ : peak friction angle

$\gamma$ : unit weight

$\gamma_{\mathrm{d}}$ : dry unit weight

G: density of solid particles

w: moisture content

$\mathrm{W}_{\text {nat }}:$ natural moisture content

$\mathrm{w}_{\mathrm{L}}$ : liquid limit

$\mathrm{w}_{\mathrm{p}}$ : plastic limit

$\mathrm{P}_{\mathrm{r}}$ : plasticity index

e: void ratio

$\mathrm{S}_{\mathrm{r}}$ : degree of saturation

ABNT: Brazilian Association of Technical Standards

ASTM: American Society for Testing and Materials

ISO: International Organization for Standardization

JCPDS: Joint Committee on Powder Diffraction Standards

SUCS: Unified Soil Classification System 